\title{
Autoimmunity in Primary Immunodeficiencies
}

\section{Magda Carneiro-Sampaio • Sudhir Gupta}

Published online: 9 April 2008

(C) Springer Science + Business Media, LLC 2008

\section{Erratum to: J Clin Immunol}

\section{DOI 10.1007/s10875-008-9181-8}

The original version of this article unfortunately contained a mistake. Dr. Sudhir Gupta was not listed as a guest editor.

The online version of the original article can be found at http://dx.doi. org/10.1007/s10875-008-9181-8.

M. Carneiro-Sampaio $(\bowtie)$

Department of Pediatrics,

Faculdade de Medicina da Universidade de São Paulo,

Av. Enéas Carvalho Aguiar 647,

05403-900 São Paulo, Brazil

e-mail: magda.carneiro@icr.usp.br

\section{S. Gupta}

Basic and Clinical Immunology Medical Sciences I, C-240,

University of California,

Irvine, CA 92697, USA 